\title{
A Procedure for Performing Population-Level Ecological Risk Assessments
}

\section{BRUCE K. HOPE*}

Oregon Department of Environmental Quality

Waste Management and Cleanup Division

811 SW 6th Avenue

Portland, Oregon 97204, USA
JEFFREY A. PETERSON

EMCON, Inc.

1475 Westec Drive, Suite 121

Eugene, Oregon 97402, USA

Re: Environmental Management 25:3, pp. 281-289: Three errors appeared in the published version of this article. These errors are:

- Equation (8) on p. 286 should read: $e=\operatorname{CRITBINOM}(n, p, 0.90)$.

- Equation (10) on p. 286 should read: $P^{*} \cong 0.012 \times \ln (n)+0.1$.

- In Table 5 on p. 288, the $P^{*}$ value for quail should be $0.15,0.17$ for shrew, and 0.17 for fish.

These changes do not affect the conclusions reached in the paper or Oregon's continuing use of the procedure for making regulatory decisions.

*Author to whom all correspondence should be addressed. 